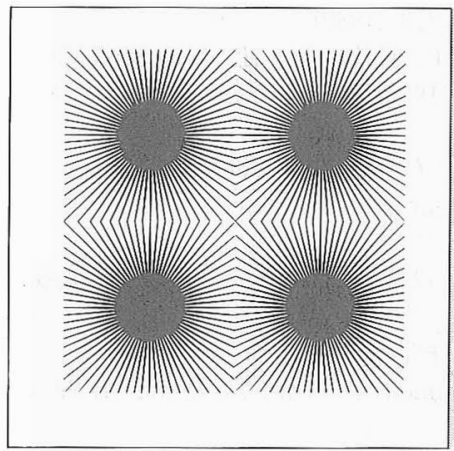

\title{
遷移金属触媒による 縮合系高分子の合成
}

柿本 雅明

Masa-aki Kakimoto, 東京工業大学工学部

\section{1.はじめに}

縮合系高分子の合成において，高分子量のポリマー を得るためには，単位縮合反応が定量的に進行するこ とが必須である。例えば，酸クロリド，酸無水物，イ ソシアナート,アルキルハライドなどの求電子㓮と, アミンやアルコールなどの求核剤との反応によるポリ アミド，ポリエステル，ポリアミド酸（ポリイミド前 駆体)，ポリ尿素，ポリウレタン，ポリエーテルなど の縮合系高分子の合成が知られている。このように， 高収率で進行する二分子間の縮合反応は，基本的に縮 合系高分子合成に応用可能であるといえる，有機金属 化学の近年の発展は目ざましく, 多くの合成化学的に 有用な反応が見いだされてきている，高分子合成の分 野では，オレフィン重合の際の Ziegler-Natta 触媒以 来，遷移金属触媒が多用されているが，縮合系高分子 の合成にこの種の触媒を活用した例はあまり多くな い.ここでは, 遷移金属触媒を使用する縮合系高分子 の合成（遷移金属触媒重縮合）について概観する

\section{2. 炭素-炭素生成反応による 縮合系高分子の合成}

遷移金属触媒重縮合における先駆的な仕事は，山本 らのポリアリーレン類の合成であろう。彼らは， Grignard 試薬と芳香族八ライドとのカップリング反 応がニッケル触媒の存在下に効率よく進行することに 注目し，例えば $p$-ジブロモベンゼン 1 にマグネシウ ムを反応させ，ついでニッケル触媒の存在下に自己縮 合させて，ポリ（pーフェニレン）2を合成した（1） 式 ${ }^{22,3)}$.この方法は, さらにチオフェン4),5) やピリジ ン6) に拡張され, 導電性高分子の化学合成法として重 要な反応となっている。上田らは（2）式に示す芳香 族ジクロリド 3 を, 亜鉛, ニッケル触媒の存在下にカ ップリングさせ，エンジニアリングプラスチックの一

Preparation of Condensation Polymers using Transition Metal Catalysts.
つである，ポリエーテルスルホン 4 を合成してい る7. ポリ( $p$ フエニレン) 2 は（3）式に示すように， 1 のニッケル触媒と電解還元との組み合わせによって も得られている8 . また，テトラヒドロキノリン 5 は レニウム触媒の存在下に脱水素重合し，ポリキノリン 6 となる〔(4) 式〕9).

以上がポリアリーレン類の合成例であるが，アルキ ルまたはアルケンの炭素と芳香族炭素との結合の形成 により進行する重合も報告されている。（5）式に示す ように, Hergenrother ら ${ }^{10)}$ と Marvel ら ${ }^{11)} は$ ，それ ぞれ独立にパラジウム錯体の存在下に, 芳香族二臭化 物 7 と芳香族ジアセチレン 8 の重縮合を試み, ポリア リーレンアセチレン9を合成している。また，ポリア リーレンジアセチレン 10 は, 銅触媒の存在下に, 芳 香族アセチレン類 8 の酸化カップリング反応によって も得られている〔(6) 式〕 ${ }^{12)}$.

芳香族ハロゲン化合物とアルケンとのカップリング 反応は Heck 反応として知られ，スキーム1 に示す反 応機構で進行すると考光られている。まず，0価のパ ラジウムが, 芳香族八ロゲン化物に酸化的付加し，ア リールパラジウム錯体 11 となる。この錯体にオレフ イン化合物が配位した後，炭素-パラジウム結合間に オレフィンがシス的に付加し， $\beta$ 水素を有するアルキ ル錯体 12 となる。この錯体 12 は不安定であるため, すぐに $\beta$ 脱離反応を起こして (シス脱離) 置換オレ フィンが生成するとともに，ヒドリド錯体 13 が生成



柿本雅明 東京工業大学工学部 有機材料工学科 (152 東京都目 黒区大岡山2-12-1）助教授, 理博

1980 年東工大大学院博士課程 修了. 1980 82 年相模中央化 学研究所, 1982 年より東工大. 専門は高分子合成，高分子薄 膜。 〈趣味〉ゴルフ 


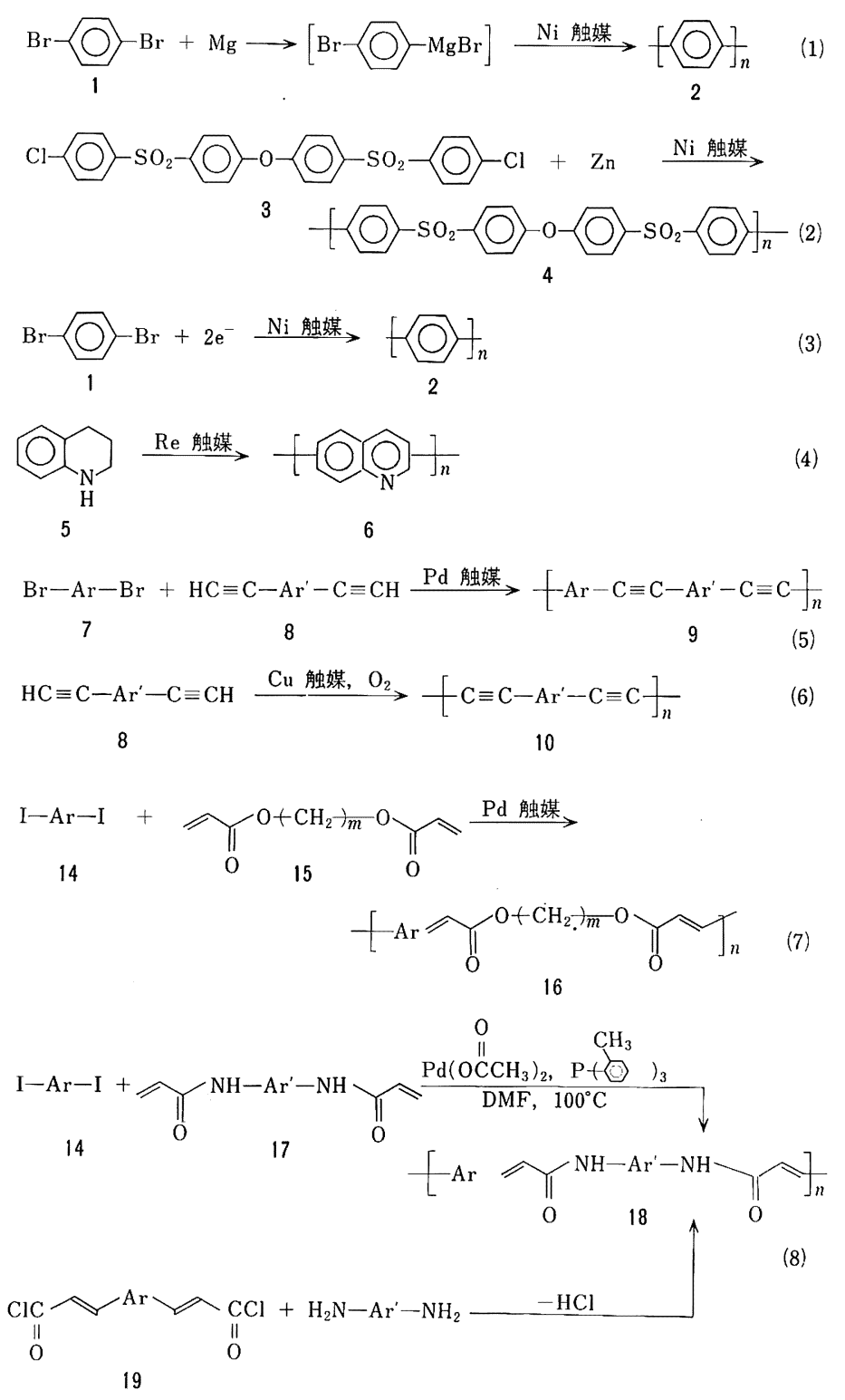

してくる.このヒドリド錯体 13 は，塩基により容易 に0 価のパラジウムに再生され, 反応は触媒的に進行 する。この反応は, 温和な条件で, しかも効率良く進 行する炭素-炭素結合生成反応であり, 得られる生成 物中は，二重結合が立体を保持したまま存在する特異 な反応である(スキーム 1$)$.

この反応を用いて，三枝らは芳香族ジョード化合物


反応により，液晶性が期待できるポリエーテル系の高 分子 16 を合成している〔(7) 式〕 ${ }^{13)}$.

われわれは, Heck 反応を, 主鎖に不飽和結合を有

高分子 38 巻 11 月号 $(1989$ 年)
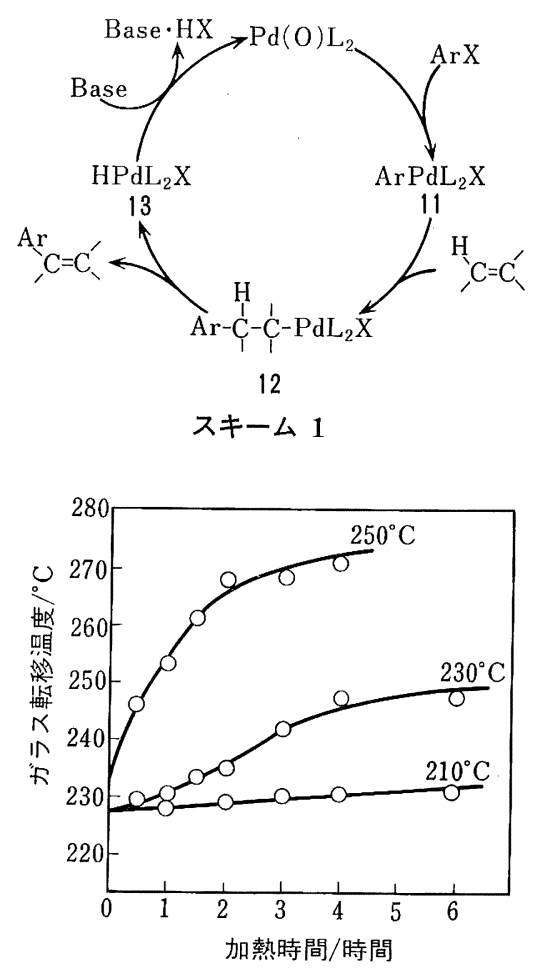

図 1 ポリアミド 18 の加熱時間と 熱硬化物の $T_{\mathrm{g}}$ との関係

する芳香族ポリアミド 18 の合成に応用 した ${ }^{14)}$ （8）式に示すように，芳香族ジ ヨード化合物 14 と, ビスアクリルアミ ド 17 と反応を，モノマーに対して 1 $\mathrm{mol} \%$ の酢酸パラジウムを触媒としてジ メチルホルムアミド中で行うと, 固有粘 度が $1.0 \mathrm{dL} \cdot \mathrm{g}^{-1}$ 以上の高分子量のポリ

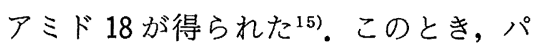
ラジウムの配位子として使用したトリト リルホスフィンの量がパラジウムに対し て 4 倍モル等量以上あると, パラジウム がパラジウム金属（パラジウムブラック）として析出 せず，最終的に得られるポリマーが着色しないことを 見いだした。ポリアミド 18 は，ジメチルホルムアミ ドなどのアミド系有機溶媒に可溶であり, 透明なフィ ルムをこれらの溶媒からキャストすることが可能であ った. また, $230^{\circ} \mathrm{C}$ 以上のガラス転移温度 $\left(T_{\mathrm{g}}\right)$ を有 し, $350^{\circ} \mathrm{C}$ 付近まで熱的に分解しない耐熱性ポリマー である。ポリアミド 18 は，主鎖に不飽和結合を有し ているので, 加熱または紫外光照射により架橋し不溶 化する。図 1 に, 18 を $T_{\mathrm{g}}$ 以下 $\left(210^{\circ} \mathrm{C}\right), T_{\mathrm{g}}$ 付近 $\left(230^{\circ} \mathrm{C}\right)$, および $T_{\mathrm{g}}$ 以上 $\left(250^{\circ} \mathrm{C}\right)$ の温度で加熱した 

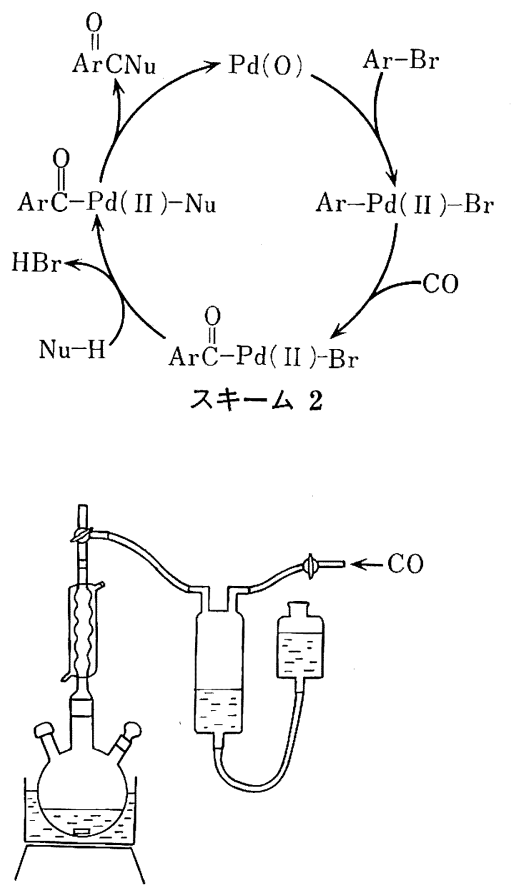

図 2 カルボニル化重合の装置

ときの加熱時間と $T_{\mathrm{g}}$ との関係を示す.いずれの場合 にも有機溶媒に不溶となったが，高温での熱処理によ り $T_{\mathrm{g}}$ は著しく上昇した。これは, 高温で加熱する と, より高密度に架橋が生成し, その結合 $T_{\mathrm{g}}$ が上昇 したのである。

ポリアミド 18 を従来法で合成するためには，(8) 式に示すように，ビスシンナモイルクロリド型の酸ク ロリド 19 が必要である. 今回の方法では, 従来法と は異なり，炭素一炭素結合生成反応により 18 を合成し たが,ここで必要となるビスアクリルアミド 17 は, 酸クロリド 19 と比べて, 合成が容易であり長期保存 性が高いという利点がある。

\section{3. 一酸化炭素を用いるカルボニル化反応 による縮合系高分子の合成}

ポリアミドやポリエステルなどのカルボニル基を有 する縮合系高分子は, 特に重要な高分子の一群であ る. 従来この種の高分子の合成は，酸クロリドなどの カルボン酸誘導体とアミンもしくはアルコールとの反 応で合成されている。パラジウム触媒を用いる合成反 応の中に, 一酸化炭素の插入反応, すなわちカルボニ ル化反応がある. 求核剤により細部の反応機構は異な るが，この反応の概要はスキーム 2 に示すとおりであ る. Heck 反応と同様に, 芳香族-パラジウム結合の
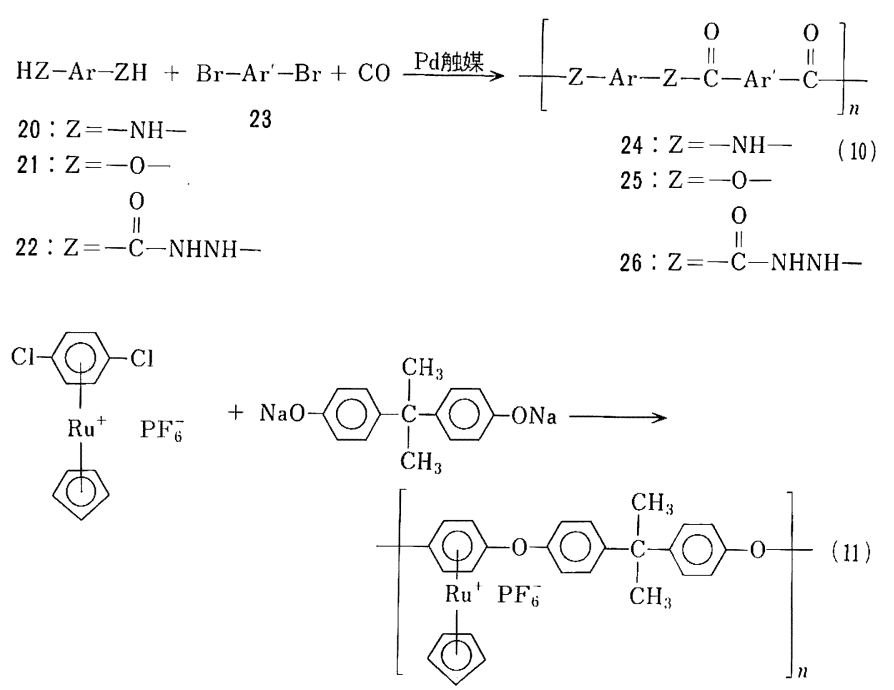

生成から反応が始まる、ついで, 炭素-パラジウム結 合間に一酸化炭素が捚入されアシル錯体となり,さら に, 求核剤がパラジウム上で置換反応を行い, 還元的 にパラジウムが脱離してカルボニル化反応が完結す る.

山本らは，前述のポリ（ $p$-フェニレン） 2 の合成を， 一酸化炭素のふん囲気下で行いポリケトンの合成を試 みたが, 一酸化炭素の挿入は完全に進行せず，いわば ポリケトンとポリ（ $p$ フェニレン）との共重合体のよ うな結合となった〔(9) 式] ${ }^{16)}$.

われわれは，(10）式に示すように14), 求核剤をジ アミン 20 , ジオール 21 , ビスヒドラジド 22 と変化さ せて, 芳香族ジブロミド 23 とのカルボニル化反応に より，相当するポリマー2 $24^{17), 18)}, 25^{19)}, 26^{20)}$ を合成 した。

重合反応には常圧の一酸化炭素を用いるため, 重合 装置は図 2 に示すような, 常圧接触還元で多用される ガスビューレットがそのまま使用できる。それぞれの 求核剂を用いる反応ごとに反応条件の詳細な検討を加 え最適化した結果, パラジウム触媒, 塩基, 反応溶 媒, 反応温度について, 表 1 のような結果を得, これ らの条件下で各個の重合反応を行った。 パラジウム触 媒は，モノマーに対して $5 \mathrm{~mol} \%$ あれば十分であっ た。 図 3 に示すポリアミド合成の場合のように，反応 時間とともにポリアミドの粘度が上昇するが，やがて 一定值となり重縮合反応が終了したことがわかる。こ の曲線は, 反応時間と一酸化炭素の消費量との関係を 
表 1 カルボニル化反応の反応条件

\begin{tabular}{clcc}
\hline ポリマー & パラジウム触媒 & 反応溶媒 & 反応温度 \\
\hline 24 & $\mathrm{PdCl}_{2}\left(\mathrm{PPh}_{3}\right)_{2}$ & $\mathrm{DMAc}$ & $115^{\circ} \mathrm{C}$ \\
25 & $\mathrm{PdCl}_{2}\left(\mathrm{PPh}_{3}\right)_{2}$ & $\mathrm{Ph}-\mathrm{Cl}$ & $115^{\circ} \mathrm{C}$ \\
26 & $\mathrm{Pd}\left(\mathrm{PPh}_{3}\right)_{4}$ & $\mathrm{DMSO}$ & $95^{\circ} \mathrm{C}$ \\
\hline
\end{tabular}

示す曲線とよく対応していることから，一酸化炭素の 消費量を測定することにより反応の進行状態を推し量 ることが可能である。このようにして得られた種々の ポリマーの固有粘度は，扔おむね $0.3 \sim 1.0 \mathrm{dL} \cdot \mathrm{g}^{-1}$ で あり，フィルムに成形可能な高重合体のポリマーも得 られたが，反応溶媒に対する溶解性の低いポリマーが 生成する場合には，あまり高重合体のポリマーは得ら れなかった。また，求核剈としてジアミン 20 を用い た場合にもっとも高粘度のポリマーが得られた。これ は，これらの求核剤の中で，ジアミンの求核性が比較 的高いためであろうと思われる。

カルボニル化反応による一連の高分子の合成におい ては, 従来カルボン酸またはその誘導体をモノマーと して使用していたのに対し，相当するジ八ライドをモ ノマーとして使用する，芳香族ジハライドは，多くの 場合カルボン酸より入手が容易であることを考える と，本方法は，特に新規な構造のポリマーを合成しょ うとする場合などにおいて有利な方法であるといえ る.

\section{4.おわりに}

触媒反応ではないが，ベンゼン環のクロムカルボニ ル錯体やルテニウム錯体を使用して，芳香族の反応性 を向上させようとする試みがあり，例えば（11）式に 示すように芳香族ポリエーテルが合成されている21).

このように，遷移金属触媒重縮合反応は，まだ始ま ったばかりであるが，従来の縮合系高分子合成では達 し得なかった結合を生成しながら反応が進行するた め，より入手が容易で，保存性に優れたモノマーが選 択でき，またある場合には，従来法で合成が困難な構 造のポリマーを容易に合成することが可能となろう。

遷移金属触媒を使用する合成反応の多様性を考える と，今後大いに発展が期待される分野である。

\section{文献}

1）今井淑夫：高分子, 37, 892 (1988)

2) T. Yamamoto, A. Yamamoto: Chem. Lett., 1977, 353



図 3 カルボニル化重合における反応時間と粘度およ び CO 消費量との関係

3) T. Yamamoto, Y. Hayashi, A. Yamamoto: Bull. Chem. Soc. Jpn., 51, 2091 (1978)

4) T. Yamamoto, K. Sanechika, A. Yamamoto: J. Polym. Sci., Polym. Lett. Ed., 18, 9 (1980)

5) T. Yamamoto, K. Sanechika, A. Yamamoto: Bull. Chem. Soc. Jpn., 56, 1497 (1983)

6) T. Yamamoto, T. Ito, K. Kubota : Chem. Lett., 1988, 153

7）上田 充，三上ひろみ，市川文明：高分子学会予稿集， 38, 300 (1989)

8) J. -F. Fauvarque, M.-A. Petit, A. Digua : Makromol. Chem., 188, 1833 (1987)

9) L.Y. Chiang, R.R. Chianelli : J. Chem. Soc., Chem. Commun., 1986, 1461

10) S.J. Havens, P.M. Hergenrother: J. Polym. Sci., Polym. Lett. Ed., 23, 587 (1985)

11) D.L. Trumbo, C.S. Marvel: J. Poly. Sci., Part A, Polym. Chem., 24, 2231 (1987)

12) A.S. Hay: J. Poly. Sci., Part A, 7, 1625 (1969)

13）鈴木将人，林鍾賛，庄克彦，三枝武夫：高分子学会予稿 集, 36, 1469 (1987)

14）米山賢, 田中正紀, 柿本雅明, 今井淑夫 : 高分子学会予 稿集, 37, 2969 (1988)

15) M. Yoneyama, M. Kakimoto, Y. Imai : $M a$ clomolecules, in press.

16）山本隆一，江原義男，山本明夫：日化誌，1982，310

17) M. Yoneyama, M. Kakimoto, Y. Imai : $M a$ clomolecules, 21, 1908 (1988)

18) M. Yoneyama, M. Kakimoto, Y. Imai : J. Poly. Sci., Part A, Polym. Chem., 27, 1985 (1989)

19) M. Yoneyama, M. Kakimoto, Y. Imai : Maclomolecules, 22, 2593 (1989)

20) M. Yoneyama, M. Kakimoto, Y. Imai : $M a$ clomolecules, in press.

21) J.A. Segal: J. Chem. Soc., Chem. Commun., 1985, 1338 (1985) 